九州大学学術情報リポジトリ

Kyushu University Institutional Repository

\title{
Of Trees and Beasts : Site Selection in Premodern East Asia
}

Goethem, Ellen van

Department of Philosophy Faculty of Humanities, Kyushu University : Associate Professor

https://doi.org/10.5109/1654559

出版情報: Journal of Asian Humanities at Kyushu University. 1, pp.1-7, 2016-03. Kyushu University, School of Letters, Graduate School of Humanities, Faculty of Humanities バージョン:

権利関係 : 


\title{
Of Trees and Beasts: Site Selection in Premodern East Asia
}

\author{
ELLEN VAN GOETHEM
}

\section{Introduction ${ }^{1}$}

$\mathbf{S}$ INCE ancient times, people in the Chinese cultural sphere have been looking for ideal sites to construct graves, found cities, build houses, etc. The practices and beliefs connected to determining these ideal sites are generally grouped under the broad label of geomancy or site divination (Ch. fengshui, Jp. füsui 風水). This paper focuses on a subcategory within site divination; it examines a practice that received its own label in Japan, namely shijin sōō 四神相応, and which may be translated into English as "correspondence to the four deities."

Shijin 四神, or "four deities," stands for the four mythical beasts fundamental to site divination practices. The term denotes the emblematic guardian deities

1 This article is an expanded version of a paper presented at the Third Conference of East Asian Environmental History (EAEH 2015), Takamatsu, Kagawa, Japan, October 22-25, 2015. I am indebted to Gina Barnes who provided valuable comments on an earlier draft and to the Japan Society for the Promotion of Science for its financial support (若手研究 A, no. 15H05376, Site Divination in Premodern East Asia).

2 It is important to note, however, that although this four-character sequence may be found only in Japanese sources, the actual divinatory practice the phrase shijin sōo refers to is in no way unique to the archipelago. of the four directions, which during the first centuries of the Common Era were consolidated as being the Vermilion Sparrow (suzaku 朱雀); the Black Warrior (genbu 玄武), which is shaped like a turtle intertwined with a snake; the Azure Dragon (seiry $\bar{u}$ 青龍); and the White Tiger (byakko 白虎). ${ }^{3}$ These beasts are customarily identified with one of the four cardinal directions in which case the Sparrow protects the south, the Turtle-Snake protects the north, the Dragon protects the east, and the Tiger protects the west. One has to keep in mind, however, that originally each of the deities was associated with a relative direction (namely, front, back, left, and right, respectively) and that the associations between mythical beast and cardinal direction were not made until after the invention of the magnetic

3 In China, these emblematic animals of the four directions are variously called sishen 四神, sixiang 四象, or siling 四靈. They need to be distinguished from another group of four divine animals (also called siling) that consists of the phoenix, the unicorn, the tiger, and the dragon and who "have the virtues of good omens." Michèle Pirazzoli-t'Serstevens, "Death and the Dead: Practices and Images in the Qin and Han," in Early Chinese Religion: Part One: Shang through Han (1250 BC-220 AD), Volume Two, John Lagerwey and Marc Kalinowski, eds. (Leiden: Brill, 2011), 963. 
compass. ${ }^{4}$ Moreover, even after the invention of the compass, a south-facing orientation and north-south alignment of the buildings or cities were not always a necessary condition for a site to be deemed auspicious, a feature site divination practices retained throughout history. ${ }^{5}$

Whereas identification of the four deities as well as their respective directions is thus straightforward, it is much more difficult to ascertain to which landscape feature each of the four was supposed to correspond. The oldest extant Chinese sources can be woefully vague as is illustrated by the following excerpt from the Inner Chapter of the fourth-century Book of Burial Rooted in Antiquity ( $G$ u ben zang jing nei pian 古本葬 經内篇), authorship of which is traditionally attributed to Guo $\mathrm{Pu}$ 郭理 (276-324):

The Classic says, 'If the land has the four configurational forces [四勢], qi [氣] will follow the eight directions.' Therefore, in burial, one has on the left the Azure Dragon, on the right the White Tiger, at the front the Vermillion Sparrow, and the back the Dark Warrior. The Dark Warrior will hang his head, the Vermillion Sparrow will soar in dance, the Azure Dragon will creep along, and the White Tiger will tamely bow his head. If the form and configurational force are in opposition to this formulation, then there will be ruin and death. ${ }^{6}$

4 The invention of the compass in China is closely related to divinatory practices. The first Chinese compasses probably appeared in the fourth century BCE and consisted of a spoon carved from lodestone that rotated on the diviner's board (Ch. shi 式). See Joseph Needham, Science and Civilisation in China: Volume 4 Physics and Physical Technology, Part 1, Physics (Cambridge: Cambridge University Press, 1962), 230 and 239, and Ivanka Charvátová, Jaroslav Klokočník, Josef Kolmaš, and Jan Kostelecký, "Chinese Tombs Oriented by a Compass: Evidence from Paleomagnetic Changes Versus the Age of Tombs," Studia Geophysica et Geodaetica 55 (2001), 160.

5 For example, while the protective mountains surrounding Jiankang 建康, the capital city of the Eastern Wu (229-65 and 266-80 CE), Eastern Jin (317-420 CE), and Southern (420-552 and 557-89 CE) Dynasties, are arranged in line with the cardinal directions, the central axis of the city itself is tilted to the northeast. In more recent times, the main gate and the throne hall of the fifteenth-century Changgyeonggung palace, another site deemed to have been auspicious, were constructed facing east instead of south. Mizuno Aki, "Shijin sōō to shihō ni haisuru shokubutsu no kōsatsu: Shijin sōō no keikan o chūshin to shite," 569 and personal communication with Hong-Key Yoon.

6 Adapted from Michael Paton, Five Classics of Fengshui: Chinese Spiritual Geography in Historical and Environmental Perspective (Leiden and Boston: Brill, 2013), 131.
Admittedly, when one continues to read the Book of Burial, it is possible to deduce that the four mythical beasts are meant to correspond to mountains and rivers, that is, to natural landscape elements. Nevertheless, as will be discussed in more detail below, documents found in the Mogao caves reveal that at least as early as the ninth, if not the seventh, century a variant site divination practice had emerged in which not only natural but also manmade landscape features were required for a site to be deemed auspicious.

Moreover, in this variant fengshui practice each of the four mythical beasts was required to correspond to its own specific feature. The Sparrow required the presence of a body of water in an open plain to the front or south of a site, the Warrior required the presence of a mountain, the Dragon that of a river, and the Tiger that of a road. It is this particular practice which requires three natural landscape features and one manmade element that in Japan is known under the phrase shijin $s \bar{o} \bar{o}$; in addition, it is deemed to be the practice that was used to select the sites where Japan's old Chinese-style capital cities - cities laid out on a grid such as Nara and Heian-were established between the late seventh and late eighth century. This is not only the case in current popular understandings of the founding of these cities, but may be found in Western and Japanese scholarship on the topic since about a century ago. Elsewhere, I have argued against this assumption that the divinatory practice known in Japan as shijin sōō and requiring those specific natural and manmade features was used for determining the location of Japan's Chinese-style capitals. In my opinion, it was a divinatory practice used to determine the ideal location for private residences and did not become connected to the siting of cities until about the thirteenth century when it started to be applied anachronistically to the founding of the Heian capital. As time progressed more cities were added to the list of sites that were purportedly selected based on the principles of shijin sōō, that is, "mountainriver-lake-road."

7 See Ellen Van Goethem, "The Four Directional Animals in East Asia: A Comparative Analysis," in Florian C. Reiter, ed., International Conference on Feng Shui (Kan Yu) and Architecture in Berlin (Asien- und Afrika-Studien der Humboldt-Universität zu Berlin 38) (Wiesbaden: Harrassowitz, 2011), 12-5. 


\section{Planting Trees to Avert Inauspiciousness}

In what follows, I will focus on the fact that among the Chinese, Korean, and Japanese sources that describe this specific divinatory practice of "mountainriver-lake-road," several texts provide a practical-and in most cases fairly easily realizable albeit not always sound-solution to remedy any shortcomings in the surrounding topography. According to these sources, lack of auspiciousness due to missing landscape features could be corrected by planting specific species of trees. In a number of cases, the sources even go so far as to specify the actual number of trees to be planted.

The oldest manuscript describing both the "mountain-river-lake-road" divinatory practice and the substitution of missing landscape features through the planting of trees is document P2615a, which was taken from the Mogao caves by Paul Pelliot $(1878-1945)$ in the early twentieth century. ${ }^{8}$ Although this one-fascicle manuscript dates from the ninth or tenth century it claims in its introduction that the text was authored by Lu Cai 呂才 (d. 665), a noted yinyang master of the Tang dynasty. Two additional Chinese sources describing a similar divination model as well as substitute trees are an illustrated book on site divination titled Tujie jiaozheng dili xinsh $u$ 圖解校正地理新書 (Illustrated and Revised New Book on Feng Shui, 1192) and a ten-volume household encyclopedia entitled Jujia biyong shilei quanji 居家必用事類全集 (Collection of Necessary Matters Ordered for the Householder, $15^{\text {th }}$ century). ${ }^{9}$ A description of the "mountain-river-lake-road" model of site divination with corresponding proxy trees also appears in an eighteenth-century Korean agricultural work entitled Sallim gyeongje 山林經濟 (Guide to Everyday Life of Rural Korean Literati, 1715) and authored by Hong Manseon 洪萬選 (1643-1715). As for Japanese sources, there is the eleventh-century Sakuteiki 作庭 記 (Notes on the Making of Gardens), a work on garden aesthetics attributed to the courtier Tachibana no Toshitsuna 橘俊綱 (1028-1094); the Hoki naiden 篮䈍 内伝 (Ritual Implement Tradition), which has tradi-

8 Although the manuscript is currently most commonly referred to under its serial number in the Pelliot collection, its original title seems to have been [...] di tui wu xing yin yang deng zhai tu jing 帝推五姓陰陽等宅図経. See Jin Shenjia, ed., Dunhuang xieben zhaijing zangshu jiaozhu (Beijing: Minzu chubanshe, 2007).

9 The Tujie jiaozheng dili xinshu is based on the no longer extant Dili xinshu 地理新書 (New Book on Feng Shui), written in the first half of the eleventh century by Wang Shu 王洙 (997-1057?). tionally been attributed to the late tenth-century court astrologist Abe no Seimei 安倍晴明 (921-1005), but of which it is now commonly accepted that the text was actually written in the early fourteenth century; and, finally, the Taishiden gyokurinsho 太子伝玉林抄 (The Biography of Shōtoku Taishi) written by the monk Kunkai 訓海 (1386-1457) of Hōryūji temple in the first half of the fifteenth century.

As mentioned before, each of these seven works provides a solution to make up for a missing landscape feature by suggesting specific tree species that could be planted as substitutes in each of the four directions (see Table 1).

When we take a closer look at the various tree species to the table, an interesting pattern emerges and two groups may be distinguished. The first group (see Table 2), comprising Dunhuang document P2615a, the Sakuteiki, and the Hoki naiden, stipulates one specific tree species to be planted to make a site auspicious if one of the required landscape features is missing.

The works in the second group (see Table 3), which comprises the four remaining works, do not set down a specific number of trees; instead they suggest two different tree species to be planted in case any of the natural or manmade features was lacking. ${ }^{10}$ What is not entirely clear here is whether one is required to plant both species of trees or whether one may choose either one of the designated trees.

Turning back to the trees suggested by the tree texts belonging to group 1, it should immediately be clear that there is very little consistency in the species suggested in each of the three sources. The sources do have two things in common, however. First, only one species is suggested for each direction, and second, the three texts of group 1 set down specific numbers of trees to be planted to make a site auspicious (see Table 4).

At first glance, the number of trees to be planted may appear as random as the tree species; however, certainly in the case of those prescribed by the manuscript of the Pelliot collection the numbers may easily be accounted

10 As an aside, an identical group division may also be discerned in the landscape features each of these works requires. The difference might seem minute but manuscript P2615a, the Sakuteiki, and the Hoki naiden, that is, the first group, require there be a broad road (大道) to the right of a site in the direction of the White Tiger, whereas the texts in the second group require the road to be long (長道). In all other directions, the requirements are identical. For more on this, see Ellen Van Goethem, "The Four Directional Animals in East Asia: A Comparative Analysis," 6. 
Table 1. Trees to remedy deficiencies in the landscape

\begin{tabular}{lllll}
\hline Primary source* & East/Left & South/Front & West/Right & North/Back \\
\hline P2615a & Chinese parasol tree & jujube & catalpa & elm tree \\
\hline Dili xinshu & $\begin{array}{l}\text { peach tree } \\
\text { willow }\end{array}$ & $\begin{array}{l}\text { flowering plum } \\
\text { jujube }\end{array}$ & $\begin{array}{l}\text { gardenia } \\
\text { elm tree }\end{array}$ & $\begin{array}{l}\text { Siberian hazel } \\
\text { apricot tree }\end{array}$ \\
\hline Sakuteiki & willow & katsura tree & catalpa & Japanese cypress \\
\hline Hoki naiden & willow & paulownia & flowering plum & pagoda tree \\
\hline Jujia biyong shilei & peach tree & flowering plum & gardenia & apple tree \\
quanji & willow & jujube & elm tree & apricot tree \\
\hline Taishiden gyokurinshōo & $\begin{array}{l}\text { peach tree } \\
\text { willow }\end{array}$ & $\begin{array}{l}\text { flowering plum } \\
\text { jujube }\end{array}$ & $\begin{array}{l}\text { gardenia } \\
\text { elm tree }\end{array}$ & $\begin{array}{l}\text { apple tree } \\
\text { apricot tree }\end{array}$ \\
\hline Sallim gyeongje & peach tree & flowering plum & mountain mulberry & apple tree \\
& willow & jujube & elm tree & apricot tree \\
\hline
\end{tabular}

* Sources are listed in chronological order.

Table 2. Substitute trees in group 1

\begin{tabular}{lllll}
\hline & East/Left & South/Front & West/Right & North/Back \\
\hline P2615a & Chinese parasol tree & jujube & catalpa & elm tree \\
\hline Sakuteiki & willow & katsura tree & catalpa & Japanese cypress \\
\hline Hoki naiden & willow & paulownia & flowering plum & pagoda tree \\
\hline
\end{tabular}

Table 3. Substitute trees in group 2

\begin{tabular}{lllll}
\hline & East/Left & South/Front & West/Right & North/Back \\
\hline Dili xinshu & $\begin{array}{l}\text { peach tree } \\
\text { willow }\end{array}$ & $\begin{array}{l}\text { flowering plum } \\
\text { jujube }\end{array}$ & $\begin{array}{l}\text { gardenia } \\
\text { elm tree }\end{array}$ & $\begin{array}{l}\text { Siberian hazel } \\
\text { apricot tree }\end{array}$ \\
\hline $\begin{array}{l}\text { Jujia biyong shilei } \\
\text { quanji }\end{array}$ & $\begin{array}{l}\text { peach tree } \\
\text { willow }\end{array}$ & $\begin{array}{l}\text { flowering plum } \\
\text { jujube }\end{array}$ & $\begin{array}{l}\text { gardenia } \\
\text { elm tree }\end{array}$ & $\begin{array}{l}\text { apple tree } \\
\text { apricot tree }\end{array}$ \\
\hline Taishiden gyokurinshōo & peach tree & flowering plum & gardenia & apple tree \\
& willow & jujube & elm tree & apricot tree \\
\hline Sallim gyeongje & peach tree & flowering plum & mountain mulberry & apple tree \\
& willow & jujube & elm tree & apricot tree \\
\hline
\end{tabular}

Table 4. Specific numbers of trees to be planted

\begin{tabular}{lllll}
\hline & East/Left & South/Front & West/Right & North/Back \\
\hline P2615a & 8 & 7 & 9 & 6 \\
\hline Sakuteiki & 9 & 9 & 7 & 3 \\
\hline Hoki naiden & 9 & 7 & 8 & 6 \\
\hline
\end{tabular}


for by taking ancient Chinese number mysticism into consideration. In the (Yellow) River Chart (Ch. hetu 河 图), an esoteric numerical diagram connected to trigram sequences mentioned in the Zhouyi 周易 (Zhou Changes, also known as the Yijing 易經 or Book of Changes), the numbers six through nine are associated with directions identical to those prescribed in manuscript P2615a. The same four numbers are also mentioned in the Hoki naiden, but the direction with which they are associated is slightly different as the position of numbers eight and nine has been reversed. Could this be the result of a simple copying error, or-at the risk of appearing facetious - could the author, deemed to have been a divination master, have simply mistaken left for right and vice versa? Or might there have been other elements at play? In any case, the numbers specified in the Sakuteiki truly stand out. There is correspondence only with the Hoki naiden in the east, as both require nine willows to be planted, but as indicated earlier, the Hoki naiden numbers may have been swapped inadvertently. On the other hand, because the Sakuteiki predates the Hoki naiden it is also possible that the requirement of planting nine willow trees as a substitute for the river flowing to the left of the site had become a well-established concept in Japan by the fourteenth century. This, however, does not explain why the other trees and numbers were not accepted. Moreover, it is also somewhat surprising that a garden manual would suggest substituting a missing river with willows, a tree species that requires a vast amount of water to grow and thrive. By planting no less than nine of these trees on a site that already lacks its requisite water supply one would in effect ruin the surrounding environment, not increase its auspiciousness.

There is a precedent for the auspiciousness associated with the number nine, however. According to the sixth-century Qimin yaoshu 齊民要術 (Essential Techniques for the Welfare of the People) by Jia Sixie 賈思氻思 (fl. sixth c.), planting nine peach trees 桃 (Jp. momo, Prunus persica) to the left of a site would benefit one's descendants and avert disaster; planting nine jujube bushes 央 (Jp. natsume, Ziziphus jujuba Mill.) to the front would be beneficial to raising silkworms and avert provincial office; planting nine catalpas 楸 (Jp. kisasage, Catalpa ovata) to the right would extend life and avert disease; and planting nine elm trees 榆 (Jp. nire, Ulmus parvifolia Jacq.) to the back would be beneficial to raising silkworms and the production of grains. ${ }^{11}$ Whereas the Qimin yaoshu suggests the same number of trees to be planted in each direction, in the Sakuteiki, the numbers for the three other directions seem almost random, especially the requirement of planting a mere three trees at the back of a site to make up for the lack of a protective mountain. Might it be the case that, since this is a garden manual, it would be relatively easy to construct some kind of artificial hillock in the required location and that the three trees may have been intended as merely adding extra protection against inauspiciousness rather than acting as substitutes for the lack of a hill?

Turning our attention to the trees suggested as substitutes in the works belonging to the second group, a much more uniform picture emerges. In fact, the uniformity in this group is so striking that it most likely points to a common source. All sources suggest to plant peach trees and/or willows to make up for the absence of flowing water to the left; flowering plums 梅 (Jp. ume, Prunus mume Sieb. et Zucc.) and/or jujube bushes should be planted to the front in the absence of a large body of water. Minute differences may be seen for the trees to be planted to the right of a site. All sources concur that planting elm trees may ward off inauspiciousness in the absence of a road, and three of the texts suggest that planting gardenia 杷 (Jp. kuchinashi, Gardenia jasminoides Ellis) will also make the site more auspicious. At first sight, the Sallim gyeongje seems to deviate from the other texts in that it suggest planting mountain mulberry 柘 (Jp. tsugekuwa, Cudrania tricuspidata) rather than gardenia to the right, but in his analysis of the Sakuteiki, landscape gardener and scholar Tamura Tsuyoshi concludes this might be a simple copying mistake. ${ }^{12}$ Slight discrepancies may also be observed in the trees suggested as substitutes for the hill or mountain protecting the back of a site. As was the case for the trees to be planted to the right, one species, namely the apricot 杏 (Jp. anzu, Prunus armeniaca $L$. var. ansu), is consistent throughout all four sources. As for the second tree species, three texts suggest planting apple trees 柰 (Jp. karanashi, Malus pumila Mill.) to the

11 Jia Sixie, Qimin yaoshu, Chinese Text Project (http://ctext.org/ library.pl?if=gb\&res=5430, last accessed February 24, 2016), and Mizuno Aki, "Shijin sōō to shokubutsu: Zōei takukyō to Sakuteiki o chūshin to shite," Ningen shakaigaku kenkyū shūroku 3 (2008), 189 and 193.

12 Tamura Tsuyoshi, Sakuteiki (Tokyo: Sagami shobō, 1964), 287. 
north; only the Tujie jiaozheng dili xinshu deviates from the norm in listing Siberian hazel 榛 (Jp. hashibami, Corylus heterophylla var. thunbergii). ${ }^{13}$

\section{Connections and Associations}

Why were these specific trees singled out to make up for deficiencies in the landscape? Of all seven works, only the Hoki naiden elaborates on this topic. According to this text, the trees listed could act as the perfect substitute because there was a natural association between the tree species and the required landform and because these landscape features, in turn, represented the habitat of each of the four deities..$^{14}$ For example, the Hoki naiden suggests that if there was no protective mountain at the back of a site, one could plant six pagoda trees (enju 槐, Sophora japonica) because these trees grow on mountaintops where the Turtle-Snake resides; or if there was no flowing water to the left of the site, one could plant nine willows (yanagi 柳, Salix sp.) as they typically grow in the vicinity of water where the Dragon lives. ${ }^{15}$ As will become clear from a more detailed analysis of the other six texts, however, the Hoki naiden does not seem to represent a clearly established tradition. Therefore, the reasons provided in the text as to why these tree species were deemed suitable may not have been widely supported either.

Because there is little agreement on suitable tree species between the texts and there does not seem to be a one-size-fits-all explanation despite the Hoki naiden's assertion that there was a close link between tree species, required landscape feature, and the corresponding beast's lair, other reasons should be explored. For one thing, in addition to being linked to

13 Ito should be pointed out that in Taishiden gyokurinshō, a variant character (㮈) is used for apple tree. Kunkai, Hōryūjizō son'eibon Taishiden gyokurinshō, Vol. 2 (Tokyo: Yoshikawa kōbunkan, 1978), 332.

14 Hoki naiden in Hanawa Hokinoichi, ed, Zoku gunsho ruijū, Vol. 31a (Tokyo: Zoku gunsho ruijū kanseikai, 1958), 403.

15 The pagoda tree is native to China but was introduced to Japan very early on because it already appears in Japan's oldest extant natural-sciences dictionary, the Honzō wamyō 本草和名 (Materia Medica with Japanese Names, ca. 918) by Fukane no Sukehito 深 根輔仁 (898-922) and the Wamyō ruijushō 和名類聚抄 (Japanese Names [for Things], Classified and Annotated, ca. 934) by Minamoto no Shitagō 源順 (911-83). Although not native to Japan, willows are already mentioned in eighth-century poetry and in the Honzō wamyō. Tamura, Sakuteiki, 283. a specific cardinal and relative direction, each of the four beasts was associated with a particular color in line with Five Phases (五行, Ch. wuxing, Jp. gogyō) theory. This may then have led to a preference for certain tree species over others. For example, the Tiger is associated with white, the color of the blossoms of the gardenia; and the Chinese parasol tree 青桐 (Jp. aogiri, Firmiana simplex) mentioned in Dunhuang document P2615a may have been chosen because its name explicitly refers to the color of the Dragon.

That said, the seasonal connection between direction and each of the beasts may have been equally important in determining preferred substitute tree species. ${ }^{16}$ The Dragon, left, and east are typically associated with spring. According to the Qimin yaoshu, willow branches were used in the spring rituals on the first day of the lunar year, and according to the Fengsu tongyi 風俗通義 (Thoroughly Explained Customs), a work on Chinese folk customs and beliefs compiled by Ying Shao 應劭 (ca. 140-204), peach blossoms were also used during spring festivities. ${ }^{17}$ The catalpa, on the other hand, was used during a festival celebrating the first day of autumn in the traditional calendar according to the Shennong ben cao jing 神農本草経 (Divine Farmer's Materia Medica), a Chinese work on agriculture and medicinal plants dating from the early centuries CE. ${ }^{18}$

Finally, the original habitat of the tree species may also have played a role in determining its suitability as a

16 The connection between the directional deities and the seasons was already made in Dong Zhongshu's 董仲舒 (179-104 BCE) Chunqiu fanlu 春秋繁露 (The Luxuriant Dew of the Spring and Autumn Annals, $2^{\text {nd }} \mathrm{c}$. BCE) and the Huainanzi tianwenxun 淮南子 天文訓 (Patterns of Heaven in the Great Brilliance of Huainan, $2^{\text {nd }}$ c. BCE). En-Yu Huang, "Comparing the Do's \& Taboos in Chinese Feng-Shui and Indian Vāstu-Shāstra Architectural Traditions," PhD dissertation (Leiden University, 2012), (http://hdl.handle. net/1887/18670, last accessed February 21, 2016), 198-200.

17 Jia, Qimin yaoshu; and Mizuno, "Shijin sōō to shokubutsu: Zōei takukyō to Sakuteiki o chūshin to shite," 189.

18 While the character 梓 is used in the Pelliot manuscript, the Sakuteiki uses 楸, a combination of the characters for "tree" and "autumn," thus emphasizing its suitability as a tree to be planted to the west. Because the species does not appear in the tenth-century Honzō wamyō it was likely introduced to Japan at a later date, possibly even after the Sakuteiki was written. Tamura, therefore, suggests that the requirement of planting catalpas to the west may have been copied directly from a Chinese source. Jin Shenjia, ed., Dunhuang xieben zhaijing zangshu jiaozhu (Beijing: Minzu chubanshe, 2007), 48; Hayashiya Tatsusaburō, ed., "Sakuteiki 作庭記," in Kodai chūsei geijutsuron (Nihon shisō taikei, Vol. 23) (Tokyo: Iwanami shoten, 1973), 243; and Tamura, Sakuteiki, 283. 
substitute for missing topographical features. Both the jujube shrub and the katsura tree 桂 (Jp. katsura, Cercidiphyllum japonicum) were native to areas in southern China or south of China explaining their positioning to the south..$^{19}$

Whatever the ultimate reason was, for private residences at least, its occupant could rest assured. Even if the surrounding landscape was not ideal-which in most cases probably was the case as each house site within a city could hardly be expected to have a "mountain-river-lake-road" configuration-planting specific trees, and medicinal ones at that, would still ensure good health and a long life, a successful career, and numerous descendants. ${ }^{20}$

\section{Bibliography}

Charvátová, Ivanka, Jaroslav Klokočník, Josef Kolmaš, and Jan Kostelecký. "Chinese Tombs Oriented by a Compass: Evidence from Paleomagnetic Changes Versus the Age of Tombs." Studia Geophysica et Geodaetica 55 (2001), 159-74.

Chōsen kenkyūkai 朝鮮研究会, ed. Sanrin keizai zen 山林 經濟 全. Keijō (Seoul): Chōsen kenkyūkai, 1914.

Clunas, Craig. Fruitful Sites: Garden Culture in Ming Dynasty China. London: Reaktion Books Ltd, 1996.

Field, Stephen L. Ancient Chinese Divination. Honolulu: University of Hawai'i Press, 2008.

Hayashiya Tatsusaburō 林屋辰三郎, ed. “Sakuteiki 作庭記.” Kodai chūsei geijutsuron 古代中世芸術論 (Nihon shisō taikei 日本思想大系, Vol. 23), 223-47. Tokyo: Iwanami shoten, 1973.

Hoki naiden. Hanawa Hokinoichi 塙保已一, ed. Zoku gunsho ruijū 続群書類従, Vol. 31a, 374-414. Tokyo: Zoku gunsho ruijū kanseikai, 1958.

Hong Manseon 洪萬選, Gyeongin Munhwasa. Sallim gyeongje 山林經濟. Seoul: Gyeongin Munhwasa, 1974.

Huang, En-Yu. “Comparing the Do's \& Taboos in Chinese Feng-Shui and Indian Vāstu-Shāstra Architectural Traditions." PhD dissertation, Leiden University, 2012.

19 Jia, Qimin yaoshu; and Hui-Lin Li, Nan-fang ts'ao-mu chuang: A Fourth Century Flora of Southeast Asia (Hong Kong: The Chinese University of Hong Kong, 1979), 83.

20 For example, gardenias were used to cure illnesses of the heart, liver, kidneys, lungs, and spleen, while 'elm sauce' was used to treat chest complaints. Clunas, Fruitful Sites: Garden Culture in Ming Dynasty China (London: Reaktion Books Ltd, 1996). (http://hdl.handle.net/1887/18670, last accessed February 21, 2016).

Jia Sixie 賈思荕思. Qimin yaoshu 齊民要術. Chinese Text Project (http://ctext.org/library.pl?if=gb\&res=5430, last accessed February 24, 2016).

Jin Shenjia 金身佳, ed. Dunhuang xieben zhaijing zangshu jiaozhu 敦煌写本宅経葬書校注. Beijing: Minzu chubanshe, 2007.

Jujia biyong shilei quanji. Chinese Text Project (http://ctext. org/library.pl?if=en\&res $=3558$, last accessed February 24, 2016).

Kunkai 訓海. Hōryūjizō soneibon Taishiden gyokurinshō 法 隆寺蔵尊英本 太子伝玉林抄, Vol. 2. Tokyo: Yoshikawa kōbunkan, 1978.

Li, Hui-Lin. Nan-fang ts'ao-mu chuang: A Fourth Century Flora of Southeast Asia. Hong Kong: The Chinese University of Hong Kong, 1979.

Mizuno Aki 水野杏紀. “Shijin sōō to shokubutsu: Zōei takukyō to Sakuteiki o chūshin to shite 四神相応と植 物一『造営宅経』と『作庭記』を中心として—.” Ningen shakaigaku kenkyū shūroku 人間社会学研究集 録 3 (2008): 161-200.

—_ "Shijin sōō to shihō ni haisuru shokubutsu no kōsatsu: Shijin sōō no keikan o chūshin to shite 四神相応 と四方に配する植物の考察—四神相応の景観構成を 中心として—.” Nihon kenchiku gakkai taikai gakujutsu kōen kōgaishū 日本建築学会大会学術梗概集 (2008): 569-70.

Needham, Joseph. Science and Civilisation in China: Volume 4, Physics and Physical Technology, Part 1, Physics. Cambridge: Cambridge University Press, 1962.

Paton, Michael J. Five Classics of Fengshui: Chinese Spiritual Geography in Historical and Environmental Perspective. Leiden and Boston: Brill, 2013.

Pirazzoli-t'Serstevens, Michèle. "Death and the Dead: Practices and Images in the Qin and Han." In Early Chinese Religion: Part One: Shang through Han (1250 BC-220 AD), Volume Two, John Lagerwey and Marc Kalinowski, eds., 949-1026. Leiden: Brill, 2011.

Tamura Tsuyoshi 田村剛. Sakuteiki 作庭記. Tokyo: Sagami shobō, 1964.

Van Goethem, Ellen. “The Four Directional Animals in East Asia: A Comparative Analysis.” In Florian C. Reiter, ed., International Conference on Feng Shui (Kan Yu) and Architecture in Berlin (Asien- und Afrika-Studien der Humboldt-Universität zu Berlin 38) (Wiesbaden: Harrassowitz, 2011), 201-16.

Wang Shu 王洙. Tujie jiaozheng dili xinshu 圖解校正地理新 書. Taibei: Jiwen shuju, 1985. 